\title{
Uranium-series dating rock art in East Timor
}

\author{
Maxime Aubert ${ }^{\mathrm{a}, \mathrm{b}, \mathrm{c}, *}$, Sue O’Connor ${ }^{\mathrm{c}}$, Malcolm McCulloch ${ }^{\mathrm{b}}$, Graham Mortimer ${ }^{\mathrm{b}}$, \\ Alan Watchman ${ }^{\mathrm{d}}$, Marc Richer-LaFlèche ${ }^{\text {a }}$

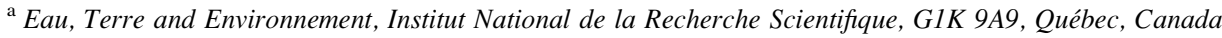 \\ ${ }^{\mathrm{b}}$ Research School of Earth Sciences, Australian National University, Canberra, Australian Capital Territory 0200, Australia \\ ${ }^{\mathrm{c}}$ Department of Archaeology and Natural History, Research School of Pacific and Asian Studies, Australian National University, \\ Canberra, Australian Capital Territory 0200, Australia \\ d 1723 Stellar Place, Montrose, CO 81401, USA
}

Received 26 April 2006; received in revised form 31 August 2006; accepted 6 September 2006

\begin{abstract}
At many sites throughout the world rock art paintings have been covered by naturally deposited calcite laminations, which we demonstrate can be individually dated by recently improved uranium-series methods. Here we report the application of multi-collector inductively coupled plasma mass spectrometry to measure the ages for carbonate coatings that bracket red pigment at Lene Hara cave, East Timor, which could be evidence of human painting. These analyses establish the feasibility of dating milligram samples of finely layered calcite deposits associated with archaeological evidence of human occupation. In addition to confirming an age of less then 6300 years for the visible red paintings on the carbonate surface we also report a substantially older age of 24,000 to 29,300 years for a similar, older red pigment lamination providing possible evidence for an earlier painting episode.
\end{abstract}

(C) 2006 Elsevier Ltd. All rights reserved.

Keywords: Rock art; Uranium-series dating; Multi-collector inductively coupled plasma mass spectrometry; East Timor; Human evolution

\section{Introduction}

Rock art is one of the most cogent signatures in the archaeological record documenting the appearance of modern humans (i.e. Homo sapiens). Artefacts (such as flaked stones) appear early in the record alongside the remains of pre-modern hominids, but even when found in clear association with modern humans, do not generally appear to be sensitive indicators of cognitive attainment. Furthermore, rock art has the unique potential to inform on symbolic expressions and cultural practices, and therefore provides one of the few "windows" into the way people thought in non-literate societies. Until the pioneering application of dating carbon in amorphous silica

\footnotetext{
* Corresponding author. Earth Environment, Research School of Earth Sciences, Australian National University, Canberra, ACT 0200, Australia.

E-mail address: maxime.aubert@anu.edu.au (M. Aubert).
}

coatings (Watchman, 1994) and layered oxalate-rich crusts (Watchman, 1993), the study of rock art was treated more as an aesthetic pursuit rather than a facet of scientific archaeology, as it had been considered impossible to date, and hence, could not be integrated with other archaeological and environmental records.

Improvements in radiocarbon dating techniques in the last 12 years have facilitated the chronometric dating of charcoal and other organic materials in painted rock art (Watchman et al., 1993; Tuniz and Watchman, 1994). However, red pigment art is usually produced using finely ground haematite mixed with water (Ward et al., 2001), and has rarely been found to incorporate contemporaneous organic materials (Watchman and Cole, 1992). Consequently, the dates obtained on haematite images can give apparent ages that are inconsistent with existing archaeological data, and raise doubts about whether or not the small quantity of organic extracts are associated with the painting episode or are later contaminants 
(Smith and Rosenfeld, 1997). Natural calcite deposits that sequentially interlay some rock paintings provide the opportunity for using uranium-series dating techniques to determine precisely when the coatings were deposited and hence bracket the timing of painting events.

\section{Background context}

Rock art complexes exist on a number of islands in SouthEast Asia (Kosasih, 1991; Ballard, 1992; Chazine, 2003; O'Connor and Oliveira, 2007), but certainly one of the largest and most diverse concentrations of painted rock art yet found is near the small village of Tutuala, at the eastern end of East Timor (Fig. 1). Rock art in this area is similar to that in other parts of South-East Asia and the western Pacific (O'Connor, 2003). Ballard (1992) has proposed an "Austronesian" origin for the painted rock art in the area stretching from Timor in the west to Vanuatu in the east. He suggested an antiquity of no more than 3500 years. With the exception of Vanuatu (Wilson et al., 2001), direct dating of the rock art has not been attempted throughout most of this region. Dates from Vanuatu confirm that the earliest artistic expression was about 3000 years BP which agrees well with dates for the earliest occupation of this region. Earlier art, pre-dating Austronesian expansion, could be found in South-East Asia and the Melanesia islands because they have far longer records of human occupation. Except for Flores (Morwood et al., 2004), most islands investigated appear to have been occupied by modern humans for at least 28,000 years (Bellwood, 1997; O’Connor et al., 2005). Sites containing painted art on East Timor have produced occupation ages as old as 35,000 BP (O'Connor et al., 2002). The recent dating of rock art in southeastern Borneo has produced a range of $\mathrm{Th} / \mathrm{U}$ and ${ }^{14} \mathrm{C}$ ages with a minimum age of ca. 9800 BP (Plagnes et al., 2003). These latest results demonstrate the presence of a painting tradition on the then Asian mainland during terminal Pleistocene times, and confirm that in some circumstances painting can endure in limestone caves in tropical environments for many thousands of years. Estimating the age of the East Timor paintings by measuring uranium-thorium values in calcite with which they are associated is essential in order to confirm the temporal and geographic consistency of the Austronesian painting tradition.

\section{Site description}

Lene Hara is a large limestone solution cave at the extreme eastern tip of East Timor (Fig. 1). It is situated at an altitude of about $100 \mathrm{~m}$ in an uplifted limestone marine terrace, which is less than $1 \mathrm{~km}$ from the current coastline. The limestone bedrock of the cave is well bedded, with folding in the limestone providing a structural control on much of the curvature of the walls and the arched cave roof. The overall architecture of the cave is open, and elliptical in cross-section, possibly reflecting an early phreatic origin (Fig. 2). Relatively thick calcite deposits cover the cave walls. Isolated large speleothem deposits occur as 2-4 $\mathrm{m}$ and $1-2 \mathrm{~m}$ high mounds within the interior of the cave, and as both thin columns and massive columnar complexes that are overlain by more recent flowstone. Active speleothem growth is restricted to minor stalactite formation.

Between 2000 and 2002, the archaeological excavations at the site have revealed that discrete time slices of the human occupation record are preserved in different parts of the cave. Test Pit A, excavated in 2000 has a basal deposit dating between 35,000 BP and 30,000 BP (O'Connor et al., 2002), and a thin upper level with Neolithic deposits containing pottery dating to $\sim 2000$ years BP. Test Pit B was located about $4 \mathrm{~m}$ east of the large ( $9 \mathrm{~m}$ diameter) speleothem column, and while its depositional sequence and depth are broadly similar to Pit A, its sediments are younger. Radiocarbon dating indicates that this deposit accumulated mostly between 26,000

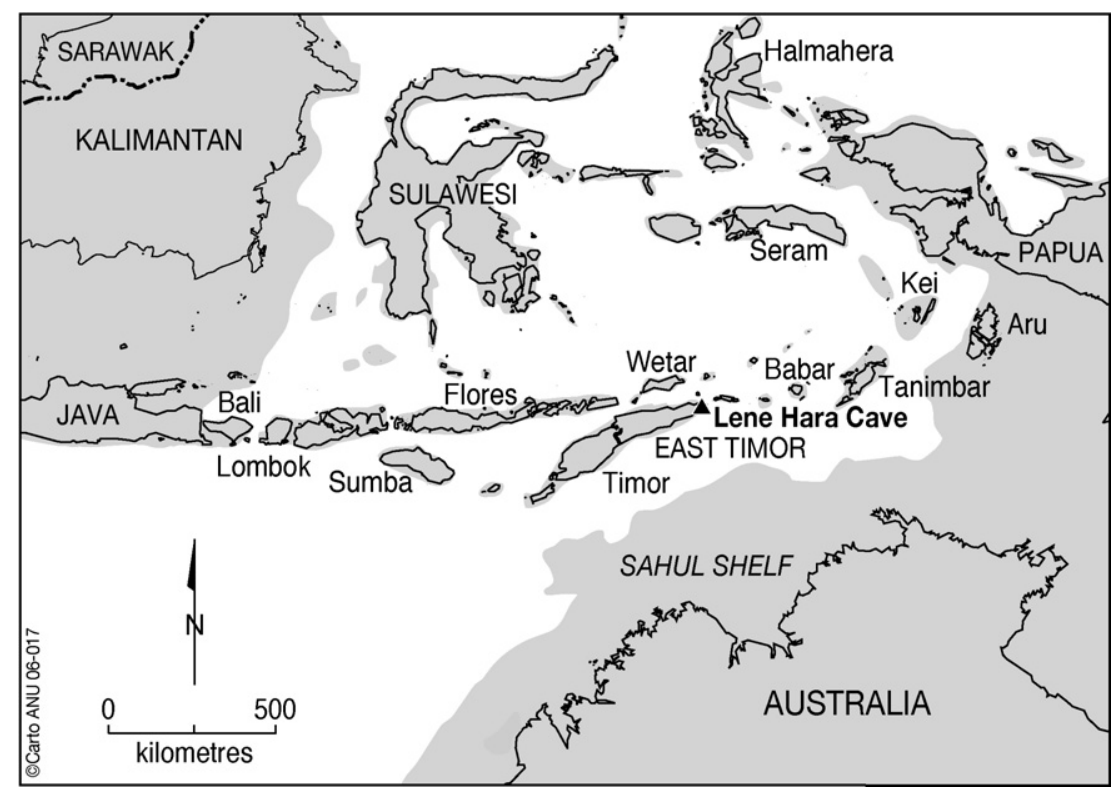

Fig. 1. Map of the Australasian-South East Asian region, showing Timor and Lene Hara cave. 


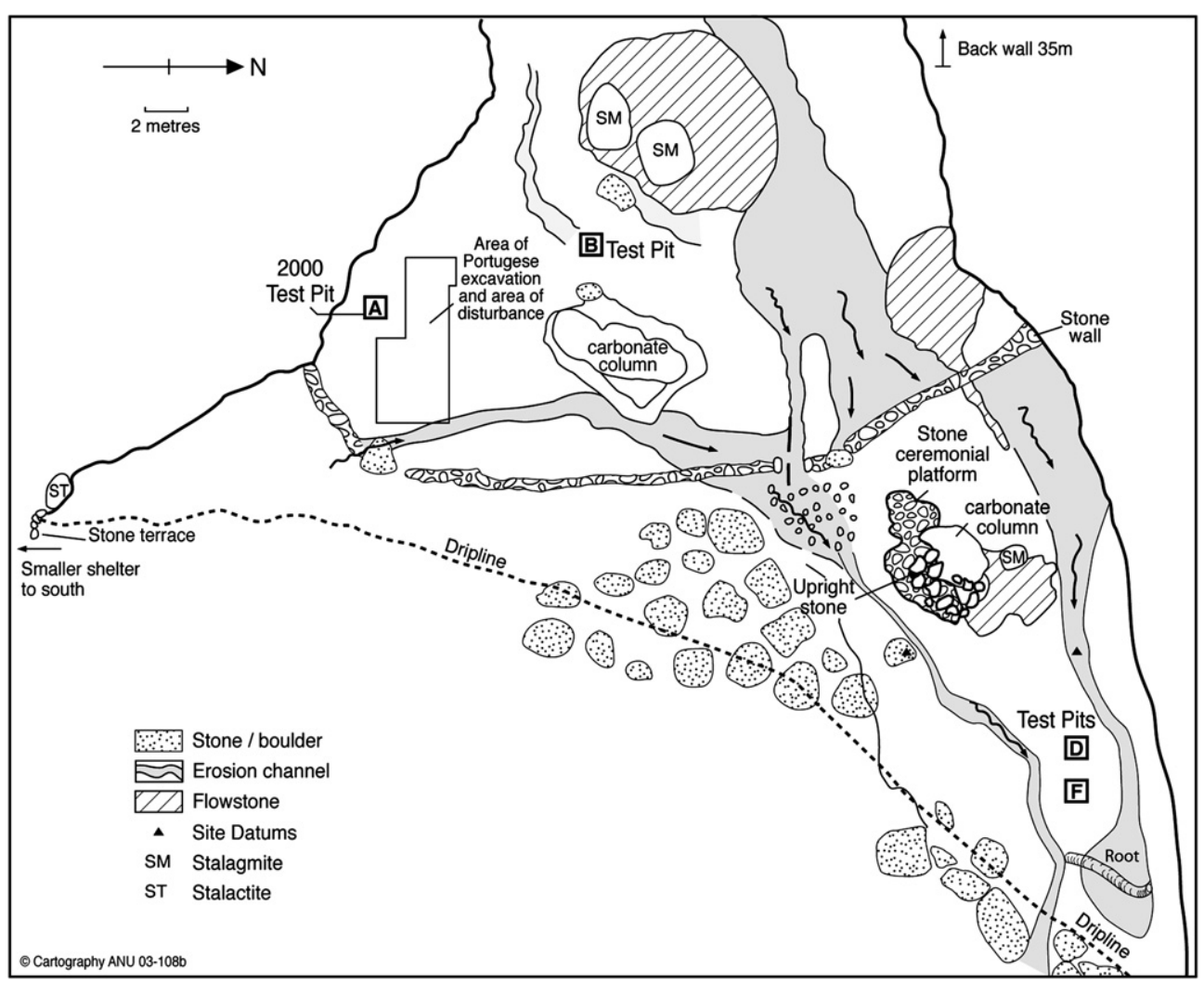

Fig. 2. Plan of Lene Hara cave.

BP and $\sim 18,000$ BP. Test Pits D and F were located $1 \mathrm{~m}$ apart and $4 \mathrm{~m}$ out from the northern wall (Fig. 2). The chronologies of the stratigraphy from Pits D and F demonstrate that all of the sampled sequence is of Holocene age dating between 1000 and 10,000 BP (O'Connor and Veth, 2005).

Rock paintings are visible today on the limestone cave walls and most are attributed to the post pottery Neolithic phase of occupation on the basis of stylistic similarities with relatively dated images from elsewhere in the western Pacific (O'Connor,
2003). Figurative motifs include small anthropomorphic figures depicted carrying objects, apparently weapons (Fig. 3). Other figurative motifs include boats, animals, such as fish shown in X-ray style and birds. Some images are zoomorphic combining human and animal features, whereas others are mixtures of geometric shapes and human features. The most common motifs in Lene Hara are non-figurative forms such as star/ sun images, circles and scrolled or linear geometric forms. Hand stencils also feature. Most motifs are monochrome red

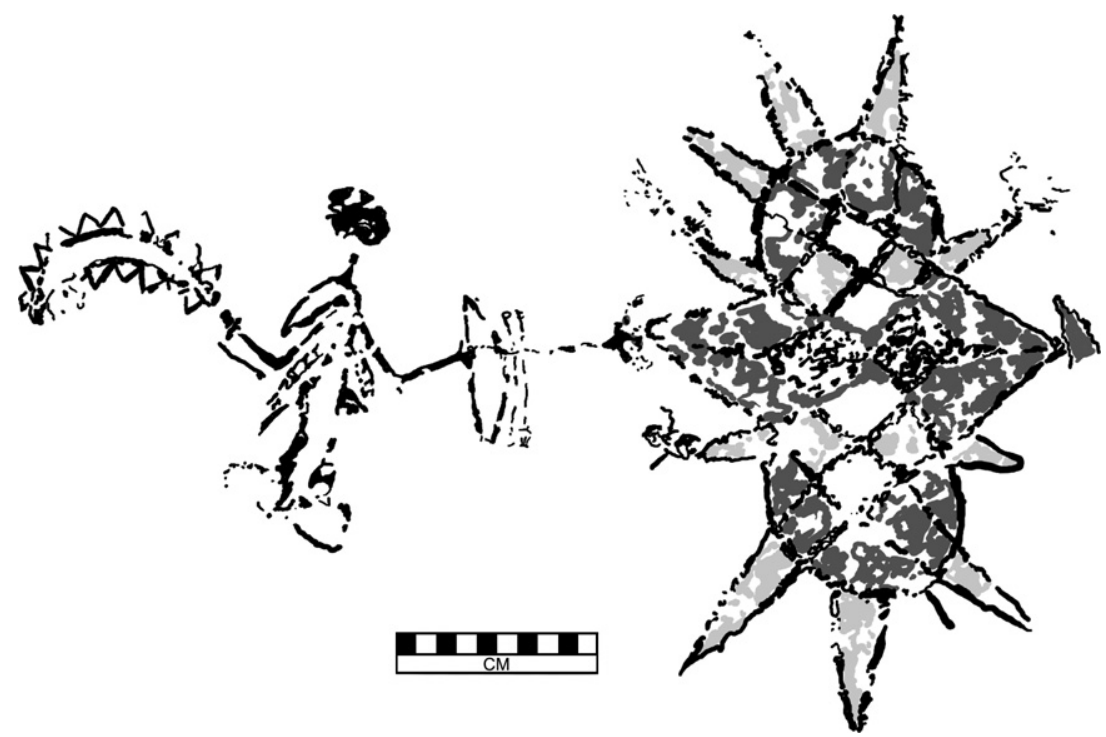

Fig. 3. Small red anthropomorph with weapons and linear geometric motif in red, black and green in style thought to post date Austronesian settlement. 
pigment, but black, yellow and brown pigments occur, sometimes as polychrome motifs. One of the linear motifs in red and black includes a faded green infill (O'Connor, 2003).

\section{Materials and methods}

Calcite coatings are formed from the deposition of dissolved calcium bicarbonate from saturated solutions that flow across the surfaces. These solutions contain small quantities of dissolved uranium and this element when deposited in a calcite coating provides the ingredient for uranium-series dating. This dating method is based on the radioactive decay chain which includes the parent ${ }^{238} \mathrm{U}$, the intermediary isotope ${ }^{234} \mathrm{U}$ and the daughter ${ }^{230} \mathrm{Th}$ (Bourdon et al., 2003). Because ${ }^{238} \mathrm{U}$ and ${ }^{234} \mathrm{U}$ isotopes are soluble in aqueous solutions but ${ }^{230} \mathrm{Th}$ is not, calcium carbonate $\left(\mathrm{CaCO}_{3}\right)$ crystals that are precipitated in calcite coatings will initially contain ${ }^{238} \mathrm{U}$ and ${ }^{234} \mathrm{U}$, but generally not ${ }^{230} \mathrm{Th}$. Subsequently, ${ }^{234} \mathrm{U}$ decays to ${ }^{230} \mathrm{Th}$. The measurement of the ${ }^{230} \mathrm{Th},{ }^{238} \mathrm{U}$, and ${ }^{234} \mathrm{U}$ isotopes allows calculation of the age of the carbonate host because the decay rate is known. The uranium-series dating method enables the determination of ages of several hundred thousand years and covers the whole time span of human history in which rock art was created.

A test specimen (off-art) was collected from the cave wall near a painted figure. This sample contains the limestone bedrock covered by a $\sim 2.5 \mathrm{~mm}$ thick calcite coating. The calcite crystal fabric covering the limestone is open columnar crystallites (Kendall and Broughton, 1978) and is characterised by a series of layers of different colours ranging from smoky grey-black to white. Those are themselves highly laminated. This fabric is $\sim 1.5 \mathrm{~mm}$ thick and terminates at a horizon indicated by a distinct continuous red layer. Above this coloured layer is a dense, finely laminated fabric $1 \mathrm{~mm}$ thick containing multi-coloured layers ranging from translucent to grey-brown.
Laser ablation inductively coupled plasma mass spectrometry (Eggins et al., 2003) was used to profile a series of elements along individual layers of interest. Uranium concentration was measured to establish sample size requirements for the determination of the $\mathrm{U}$ and $\mathrm{Th}$ isotopic ratios. Under $30 \times$ magnification the fine carbonate laminations were ground into fine powders using a micro-drill and dental burrs, maintaining control over the micro-stratigraphic level (Watchman, 2000). An area measuring approximately $1 \mathrm{~cm} \times 1 \mathrm{~cm}$ was removed to a depth of about $0.1 \mathrm{~mm}$ per sample and the powder collected on aluminium foil.

Each sample was then dissolved in nitric acid, spiked and prepared according to the method described by Luo et al. (1997). Isotopic ratio measurements were made on a Finnigan Neptune multi-collector ICPMS equipped with desolvating nebuliser. Due to its significantly higher ionisation efficiency than thermal ionisation mass spectrometry (TIMS), multicollector inductively coupled plasma mass spectrometry (MCICPMS) permits the analysis of samples with much lower $U$ concentrations in smaller samples. For example, TIMS usually requires about $100 \mathrm{ng}$ of Th while MC-ICPMS needs less than 10 (Nakai et al., 2001). The method has therefore a much wider applicability on rock coatings, where often only minute sample masses are available. Furthermore, it allows for greater spatial resolution and minimises the visual aspect of sampling. This technology also enables the potential use of laser ablation for in situ uranium series dating of rock art where U concentrations are higher then 1 ppm (Eggins et al., 2005).

\section{Results and discussion}

Fig. 4 illustrates the chemical spectrum and summarises the analytical data measured by solution MC-ICPMS for a sectional profile through the calcite chip from Lene Hara cave.
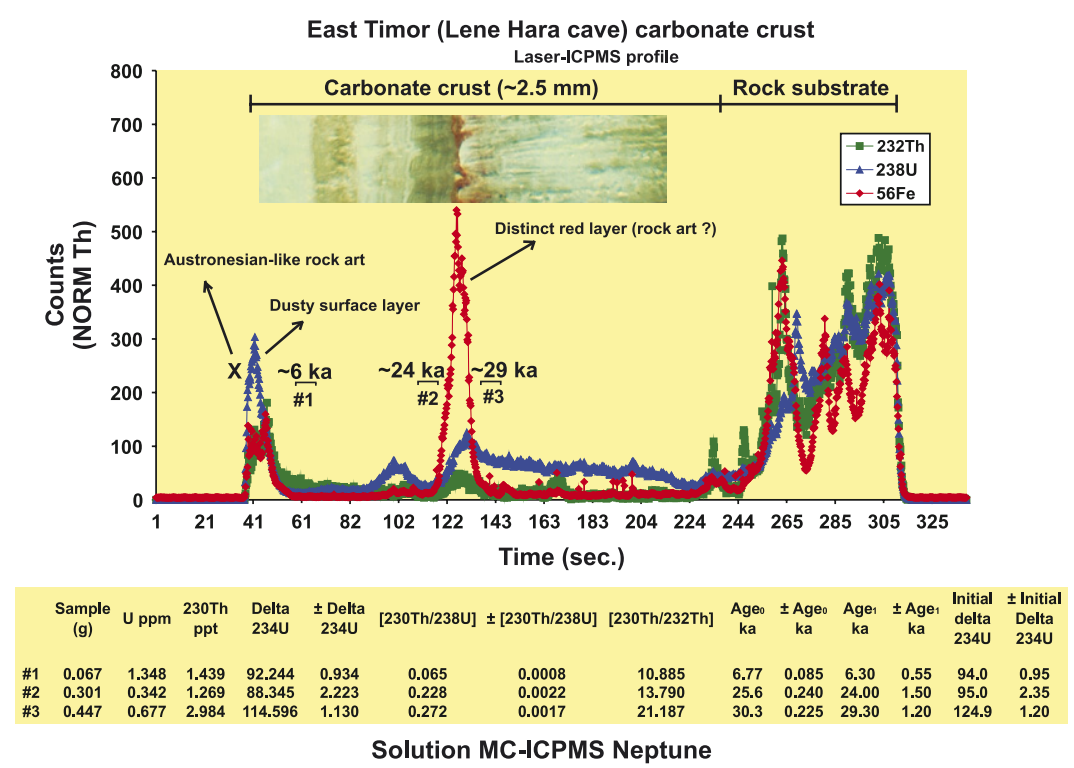

Fig. 4. Chemical spectrum obtained from the laser ablation ICPMS analysis of a sectional profile across a small chip of calcite from Lene Hara Cave, East Timor. The surface layer of paint is younger than $6 \mathrm{ka}$, and the older red pigment layer, which could also be paint, is bracketed between 24 and $29 \mathrm{ka}$. The table summarises the analytical data measured by solution MC-ICPMS. Values for Age ${ }_{1}$ are corrected ages assuming an initial ${ }^{230} \mathrm{Th} /{ }^{232} \mathrm{Th}$ ratio for Bulk Earth at secular equilibrium $=0.8 \pm 0.8$. 
A small correction for initial ${ }^{230} \mathrm{Th}$ was made to each Th analysis on the basis of the ${ }^{230} \mathrm{Th} /{ }^{232} \mathrm{Th}$ ratio for Bulk Earth at secular Equilibrium $(0.8 \pm 0.8)$. This value is commonly used for initial Th corrections in the absence of independent data (Bourdon et al., 2003). For all our samples, this correction was small because of low ${ }^{232} \mathrm{Th}$ concentrations.

The spectrum, microstratigraphy and analytical measurements indicate that the visible paintings on the surface are younger than 6300 years old. This suggests an Austronesian origin for the recent paintings, as previously argued on the basis of their formal attributes and associations based on style.

The distinct red layer observed within the pale carbonate deposit beneath the present red paintings at a depth of $1 \mathrm{~mm}$ is possibly the remnants of a much older painted image. This red layer was bracketed between 29,300 and 24,000 years old using laminations less than $0.1 \mathrm{~mm}$-thick under and overlying the red layer (Fig. 4). Such a painting is plausible because the Lene Hara cave is one of the oldest Homo sapiens sites in South-East Asia and was occupied at that time. Several pellets of red ochre found amongst other cultural material in the Pleistocene levels of the archaeological excavations at Lene Hara must have been introduced into the cave by the human occupants for painting or other decorative purposes, as no iron rich deposits occur within the cave. A significant flow of iron-rich water through the site would have been necessary to deposit a natural iron oxide layer on the cave walls and the effects of such an unusual stream should have been evident in the stratigraphy at the excavation pits. As no iron enrichment or natural iron deposit was found in the sediments and as no current iron-rich seepages exist on the cave walls or floor it seems doubtful that the red layer encapsulated in the calcite wall coatings is natural. Nevertheless, specialised analysis of the red layer is required to identify the constituents, such as organic binders and mineral phases to confirm its anthropogenic origin as paint. If this red layer is indeed a paint layer, and not a natural lamination (noting that nothing similar is seen on the adjacent rock surfaces), then its age challenges orthodox models for the age of the rock art and the makers of the rock art in eastern South-East Asia. Thus the socio-cultural use and practice of rock art in the region, which have been previously attributed only to Austronesian influence, should be revised.

\section{Conclusion and perspective}

This study shows that natural calcite laminations covering rock paintings can provide the means for bracketing those anthropogenic artefacts in age. This is possible because each sub-millimetre-thick carbonate lamination can now be precisely and accurately studied, chemically and isotopically analysed, and dated at extraordinary and unprecedented spatial and temporal resolutions using multi-collector inductively coupled plasma mass spectrometry. Application of the uranium-series dating method at the sub-millimetre scale therefore enables the dating of haematite paintings on carbonate deposits where the pigments have not been combined with organic binders, and where radiocarbon dating is unreliable because of mixing of carbon from different sources. We believe that this innovative technique provides a new level of sophistication in the research of rock art on a world scale, and can be used to enhance our understanding of the evolution of human symbolic thought and cognition.

\section{Acknowledgements}

The research in East Timor was undertaken under the auspices of the Ministério da Educação, Cultura, Juventude e Desporto de Timor-Leste. We would also like to acknowledge the support of the people of Tutuala.

\section{References}

Ballard, C., 1992. Painted rock art sites in eastern Melanesia: locational evidence for an "Austronesian" tradition. In: McDonald, J., Haskovec, I. (Eds.), State of the Art Regional Rock Art Studies in Australia and Melanesia. Occasional AURA publication No. 6. Australian Rock Art Research Association, Melbourne, pp. 94-106.

Bellwood, P., 1997. Prehistory of the Indo-Malaysian Archipelago. University of Hawaii Press, Honolulu.

Bourdon, B., Henderson, G.M., Lundstrom, C.C., Turner, S.P., 2003. Uraniumseries geochemistry. Rev. Mineral. Geochem. 52.

Chazine, J.-M., 2003. Rock art and ceramics in east Borneo: logical discovery or new cornerstone? In: Sand, C. (Ed.), Pacific Archaeology: Assessments and Prospects. Proceedings of the International Conference for the 50th anniversary of the first Lapita excavation (July 1952), Koné-Nouméa 2002, 15. Le Cahiers de l'Archéologie en Nouvelle-Calédonie, Nouméa, pp. 43-52.

Eggins, S., Grün, R., Pike, A.W.G., Shelley, M., Taylor, L., 2003. ${ }^{238} \mathrm{U}$ and ${ }^{232}$ Th profiling and U-series isotope analysis of fossil teeth by laser ablation-ICPMS. Quaternary Sci. Rev. 22, 1373-1382.

Eggins, S.M., Grün, R., McCulloch, M.T., Pike, A.W.G., Chappell, J., Kinsley, L., Mortimer, G., Shelley, M., Murray-Wallace, C.V., Spötl, C., Taylor, L., 2005. In situ U-series dating by laser ablation multi-collector ICPMS: new prospects for Quaternary geochronology. Quatern. Sci. Rev. 24 (23-24), 2523-2538.

Kendall, A.C., Broughton, P.L., 1978. Origin of fabrics in speleothems composed of columnar calcite crystals. J. Sediment. Petrol 48, 519-538.

Kosasih, E.A., 1991. Rock art in Indonesia. In: Bahn, P., Rosenfeld, A. (Eds.), Rock Art and Prehistory, Oxbow Monograph 10. Short Run Press, Exeter, pp. 65-77.

Luo, X., Rehkämper, M., Lee, D.-C., Halliday, A.N., 1997. High precision ${ }^{230} \mathrm{Th} /{ }^{232} \mathrm{Th}$ and ${ }^{234} \mathrm{U} /{ }^{238} \mathrm{U}$ measurements using energy filtered ICP magnetic sector multiple collector mass spectrometry. Int. J. Mass Spectrom 171, 105-117.

Morwood, M.J., Soejono, R.P., Roberts, R.G., Sutikna, T., Turney, C.S.M., Westaway, K.E., Rink, W.J., Zhao, J.-X., van den Bergh, G.D., Due, R.A., Hobbs, D.R., Moore, M.W., Bird, M.I., Fifield, L.K., 2004. Archaeology and age of a new hominin from Flores in Eastern Indonesia. Nature 431, 1087-1091.

Nakai, S., Fukuda, S., Nakada, S., 2001. Thorium isotopic measurements on silicate rock samples with a multicollector inductively coupled plasma mass spectrometer. Analyst 126, 1707-1710.

O'Connor, S., 2003. Report of nine new painted rock art sites in East Timor in the context of the western Pacific region. Asian Perspect 42 (1), 96-128.

O'Connor, S., Oliveira, N.V., 2007. Inter and intra regional variation in the Austronesian painting tradition: a view from East Timor. Asian Perspect 46 (2).

O'Connor, S., Veth, P., 2005. Early Holocene Trochus shell fish-hooks from East Timor. Antiquity 79, 1-8.

O'Connor, S., Spriggs, M., Veth, P., 2002. Excavation at Lene Hara establishes occupation in East Timor at least 30,000-35,000 years ago: results of recent fieldwork. Antiquity 76, 45-50. 
O’Connor, S., Aplin, K., Szabò, K., Pasveer, J., Veth, P., Spriggs, M., 2005. Liang Lemdubu, a Pleistocene cave site in the Aru Islands. In: O'Connor, S., Spriggs, M., Veth, P. (Eds.), The Archaeology of the Aru Islands, Eastern Indonesia. Terra Australis 23. Pandanus Press, Canberra, pp. 171-204.

Plagnes, V., Causse, C., Fontugnew, M., Valladas, H., Chazine, J.-M., Fage, L.-H., 2003. Cross dating (Th/U-14C) of calcite covering prehistoric paintings in Borneo. Quaternary Res. 60, 172-179.

Smith, C., Rosenfeld, A., 1997. The uses of radiometric and stylistic approaches to rock art dating. Antiquity 72 (272), 405-411.

Tuniz, C., Watchman, A.L., 1994. The ANTARES AMS spectrometer. Accelerators and lasers for dating rock art in Australia. Rock Art Research 11 (1), 71-73.

Ward, I., Watchman, A.L., Cole, N., Morwood, M., 2001. Identification of minerals in pigments from aboriginal rock art in the Laura and Kimberley regions, Australia. Rock Art Research 18 (1), 15-23.
Watchman, A.L., 1993. Evidence of a 25,000-year-old pictograph in northern Australia. Geoarchaeology 8 (6), 465-473.

Watchman, A.L., 1994. Radiocarbon dating fatty acids in Holocene siliceous rock surface accretions. Aust. J. Earth Sci. 41, 179-180.

Watchman, A.L., 2000. Micro-excavation and laser extraction methods for dating carbon in silica skins and oxalate crusts. In: Ward, G.K., Tuniz, C. (Eds.), Advances in Dating Australian Rock-Markings. Occasional AURA Publication 10, pp. 35-39.

Watchman, A.L., Cole, N., 1992. Accelerator radiocarbon dating of plant-fibre binders in rock paintings from northeastern Australia. Antiquity 67, 355358.

Watchman, A.L., Lessard, R.A., Jull, A.J.T., Toolin, L.J., Blake Jr., W., 1993. ${ }^{14} \mathrm{C}$ dating of laser-oxidized organics. Radiocarbon 35 (2), 331-333.

Wilson, M., Spriggs, M., Lawson, E., 2001. Dating the rock art of Vanuatu: AMS radiocarbon determinations from abandoned mud-wasp nests and charcoal pigment found in superimposition. Rock Art Research 18, 24-32. 